\title{
Going Green: Women Entrepreneurs and the Environment
}

\author{
Dr Patrice Braun, Deputy Director \\ Centre for Regional Innovation \& Competitiveness, University of Ballarat \\ POBOX 691 \\ Ballarat, Vic. 3353, Australia \\ Tel: +61-3-5327-9465 Email: p.braun@ballarat.edu.au \\ Website: www.cric.com.au
}

\begin{abstract}
:
In economically challenging times business operators are looking for clever and affordable ways to grow their enterprises. This paper discusses the role of women entrepreneurs' in proactively greening their small business. The paper highlights the combined outcomes of the exit survey of a greening small business 2008 pilot program and the entry survey for the 2009 online version of the training and networking program, which fuses environmental, business and ICT-enabled skilling to enhance both SME entrepreneurship and innovation. The study suggests that while reported environmental attitudes between male and female entrepreneurs do not differ significantly, women's motivations differ from male entrepreneurs in terms of greening their business; and women are more proactive in pursuing green networking opportunities, where they can interact with like-minded businesses, access more clients, source alternative resources and expand their green business networks.
\end{abstract}

Keywords: environment, gender, behaviour, green entrepreneurship, green practices; environmental motivations. 


\section{Introduction}

Placing today's social, economic, and cultural challenges, as well as environmental ones, at the core of a company's strategy is no longer mere lip service; it's considered the key to sustained success (Werbach, 2009).

The movement toward environmentally responsible enterprises is growing worldwide. Driven by a desire to integrate corporate responsibility and sustainability principles into their businesses, many entrepreneurs are finding that running a green enterprise is a sound business propositions because they can tap into new as well as existing markets. Indeed, regulation, the Corporate Social Responsibility (CSR) agenda, economic instruments and enhanced efficiency have emerged as key drivers in today's economy (Bansal \& Roth, 2000). With governments increasingly interested green jobs to create new economic opportunities in response to the twin challenges of climate change and economic downturn economically difficult times (Environment Victoria, 2009), supporting structures are being put in place to assist entrepreneurs in benefiting from the green enterprise markets and heightened consumer environmental consciousness.

Much has been written about corporations going green, but much less is known about small and micro business behaviour vis-à-vis green entrepreneurship. Green enterprise holds many possibilities for both the environment and for entrepreneurs. It can protect natural resources, lower operating costs through reduced waste and pollution, and contribute to more sustainable community economic development, while giving entrepreneurs a new and different edge to succeed in the market. So-called proactive environmental strategies can minimise a firm's negative impact and maximise its positive effects on the environment (Lepoutre \& Valente, 2007). Lepoutre (2008, p.46) defines proactive environmental strategies as "the continuous process of resource building, selection and deployment for value creation and distribution, by navigating through and interacting with the structural and social conditions that influence their value, with the purpose to prevent negative effects, or create positive impacts on the natural environment, beyond what is legally required or accepted as standard practice". Isaak (1998) uses the expression 'ecopreneur' or individuals who pursue social and ecological goals by means of profit orientated green businesses.

In the process of defining what makes a green entrepreneur, researchers have attempted to understand why firms embrace environmentally friendly practices (e.g., Bansal and Roth, 2000). Studies have identified regulatory compliance, competitive advantage, stakeholder pressures, ethical concerns, critical events and top management initiatives as motives for corporate environmental initiatives (Paulray, 2008; Bansal and Roth, 2000).

This paper provides an overview of an Australian government sponsored green entrepreneurship program entitled SmartGreen: An Entrepreneurial Approach to Greening Small Business and highlights the combined outcomes of the exit survey of a greening small business 2008 pilot program and the entry survey for the 2009 online training and networking version of the program, which fuses environmental, business and ICT-enabled skilling to enhance both small business entrepreneurship and innovation. In particular, this paper focuses on women's behavioural approaches to greening their business and asks whether there were any notable facts pertaining to the adoption of green practices by women entrepreneurs.

\section{SmartGreen}

Funded as a two-year program by the Australian government and designed as a partnership between the regional City of Ballarat, the Committee for Ballarat and the University of Ballarat's Centre for Regional Innovation \& Competitiveness and National Centre for Sustainability, the premise for the SmartGreen: An Entrepreneurial Approach to Greening Small Business program was that the greening of a small business not only depends on an awareness and demand for environmental innovation by potential users, but also on the supply of expertise and technology from those businesses who supply green products and services.

Benchmark levels of environmental efficiency vary significantly between companies, between regions and between industries. But why? It is partly because of different levels of awareness of users, but is also a reflection on the availability and strength in the supply and provision of environmental 
expertise by specialist providers. Businesses wanting to become environmentally more sustainable are limited in a similar way.

Thus there are two significant issues this program addresses. One is the economic and moral pressure for businesses of all sizes to go green and reduce their environmental footprint, but who do not necessarily know where to start, how to go about greening their business or who to engage to help them green their business. The other is the need to boost capacity, expertise and innovation on the supply side to ensure there is sufficient and high quality assistance available to help businesses to become more environmentally sustainable. Based on this design, anticipated program outcomes include benefits for both the demand and supply side.

On the supply side, through a process of technical and entrepreneurship training we see a growth of capability and ultimately a growth in these businesses. These businesses will 'push' green services and awareness after the completion of this program and work with users to develop the cluster through innovation and developing business networks. On the demand side, we see improved resource use, greater efficiency and business growth driven by lower costs and improved resource efficiency.

Building on the above premise, the program had two major aims: (1) development of a comprehensive program of entrepreneurial training and mentoring to increase supply-side capability, and (2) through a process of auditing and training of demand-side businesses the program informs regional businesses of the efficiency gains that can be made from going green and identifies and increases the demand for these services. The program then clusters available expertise, information and learning in the MySmartGreen ${ }^{\mathrm{TM}}$ portal to provide access to information, training, green products and services and encourage small businesses across the region to work towards a Green Cluster Code of Practice, whereby firms commit to excellence in sustainability through sustainable development practices, partnerships, and continual improvement. The Green Cluster Code of Practice is aligned with existing environmental management approaches and designed to provide firms with an applicable base towards future accreditation such as ISO 14000, 14080 and 14068.

In Year 1 (2008) a pilot program was rolled out to 30 micro and small to medium enterprise (SME) businesses, targeting a mix of demand-side and supply-side micro and small business suppliers of green products or services. Based on established entrepreneurship objectives, the program provided nine learning modules in business planning, marketing, risk management, service development and expansion of client base, environmental compliance training, technology and knowledge acquisition, collaboration with other suppliers of green products/services, and identification of best practice. The in-depth training and mentoring program was delivered over a 12-months period, during which participating businesses developed an environmental action plan (EAP). Participants were equally divided in terms of gender and included both manufacturing and service sector industries.

During the course of Year 1, the project team designed and built the SmartGreen portal and start collating the content for MySmartGreen online (www.mysmartgreen.com). The portal supports the information generation and networking component of this project. Portal development was also based around flexible delivery of Year 1 workshop content and related Green Cluster Code of Practice objectives. By using a clustering and social networking approach, an online learning environment and business-to-business (B2B) community was established whereby small business operators are able to access business and best practices knowledge towards triple bottom line outcomes for their individual businesses. In Year 2 of the program (2009) an awareness raising program was set up to target and enrol a wider catchment of SME businesses. Online forum discussions, EAP support and mentoring are made available to businesses as required. To date 38 businesses have enrolled, approximately half of which are women-led businesses.

Prior to providing highlights of the combined results of these methods, the paper briefly reviews key behavioural literature that underpins the design of the SmartGreen entrepreneurship program.

\section{Behavioural Literature}

The energy crisis in the USA lead to an increased interest in understanding means through which households could reduce their energy consumption to cope with the rapid increase in energy costs (Stern, 2002), in programs often funded by the US Department of Energy and the National Academy of Sciences under the direction of Paul Stern. A number of recent literature reviews summarise the studies conducted in this area (cf. Lutzenheiser, 1993; Abrahamse et al, 2005; Wilson \& Dowlatabadi, 2007), which the reader is referred to for further details of studies in this area. 
The ecopreneurship and environmental entrepreneurship literature tends to focus on innovative behaviour of single actors in business as a core objective of competitive advantage. Thus, green entrepreneurs are those that identify market opportunities and successfully implement innovative approaches to their product or service. Thus, green entrepreneurs identify environmental innovations and their market opportunity and successfully implement these innovations resulting in new products or services (Dixon \& Clifford, 2007).

Building on the premise that green entrepreneurship in micro and small to medium enterprises (SMEs) is directly linked to single actor actions, e.g. the firm's owner or manager, this paper explores environmentally significant behaviour as a joint function of psychology, social structures, economic, technology and other variables (Stern, 1992). Wilson and Dowlatabadi (2007) make the distinction between the personal and the contextual in their review of energy use behaviour, drawing on Guagnano, Stern and Dietz's (1995) "attitude-behaviour-context" model of pro-environmental behaviours.

\section{Individual models of behavioural change}

The study of individual behavioural change has long been of interest across a variety of fields interested in influencing the decisions of individuals. Marketers are interested in influencing product choices, public health practitioners in influencing health-related behaviours, and, in the case of this paper, governments and environmentalists in influencing business choices of pro-environmental behaviours. By far the most common model used as the basis for assessing the effectiveness of such interventions is the Theory of Reasoned Action (TRA) (Fishbein and Azjen, 1976) and it's extension, the Theory of Planned Behaviour (TPB) (Azjen, 1992).

The theory of reasoned action posits that certain individual behaviours can be seen as the result of a reasoned decision-making process based on the development of intent to act in a particular way, and the subsequent fulfilment of that intention. As such, the theory focuses on the prediction of behavioural intentions, particularly behavioural norms (the belief that engaging in the behaviour will fulfil normative expectations of the individual) and attitudes towards the behaviour. The extension of the model, the theory of planned behaviour (Azjen, 1992), also incorporates perceived control over the completion of the behaviour as an additional predictor, to account for those situations where the individual's capacity to engage in the behaviour may not be entirely within their control.

There are numerous studies which have used the TRA/TPB model to examine pro-environmental behaviours, although a recent meta-analysis of TPB results did not identify any specific studies of residential energy use is less common (Wilson and Dowlatabadi, 2007). In this meta-analysis, the TPB was found to explain 27 percent of the variance in behaviour, and 39 percent of the variance in behavioural intentions, suggesting an important role for the study of psychological determinants of behaviours.

The inclusion of environmental attitudes has largely been based on the New Environmental Paradigm (Dunlap and Reilly, 1978) and its revised version, the New Ecological Paradigm (Dunlap et al, 2000), known generally as the NEP. The NEP examines environmental attitudes with a combination of 15 items, and show that these items correlate to form a uni-dimensional scale which has been used extensively in the literature for further analysis and understanding individual decisions in context.

\section{Methodology}

The methodology adopted for this study was a combination of two surveys and in-class attendance and observation during the Year 1 program.

In order to develop a long-term sustainable training program from the pilot and to measure the impact on behaviour change by individuals and their firms, Year 1 participants were asked to record their program experiences after each workshop and take an exit survey after completion of the Year 1 indepth program. The Year 1 program exit survey consisted of an open-ended questionnaire designed to collect responses as to the usefulness of the content provided (with a view of transferring content to the Year 2 SmartGreen online environment), measure overall value of time spent at the SmartGreen workshops, measure the value of mentoring in terms of the development of an environmental action plan (EAP), and gauge the impact on behavioural change and viewpoints based on learning and in-class interaction. 
The Year 2 SmartGreen online entry survey is not mandatory. Program participants have a choice of paying the full fee $(\$ 180+G S T)$ to access and participate in the online program or be eligible for a $\$ 30$ discount by filling in the online entry survey conducted via the SmartGreen website. The predominantly closed-ended entry survey was designed to gauge firms' current behaviour and intended behaviour, which at the end of the program (late 2009) will assist in evaluating firms' actual behavioural change after program completion.

The Year 2 online survey, which continues to be up and running, consists of a series of questions, including questions pertaining to information sources and questions adopted from the New Ecological Paradigm (NEP), asking participants to which extent they are engaged in sustainable practices. The survey also includes a set of questions on entrepreneurial orientation to gauge the level of entrepreneurial risk taking vis-à-vis changing to green businesses practices such as sourcing new products and supply chains. The study uses Lime Survey data collection software.

\section{Findings}

At the time of this writing, of the 38 firms which enrolled in the Year 2 online program, only nine firms chose to go the discount/survey route, five of which were women-led businesses. Given that entry survey numbers are small, an indicative reporting approach was adopted for this paper, as displayed in the tables below. In the discussion section, indicative results will be discussed and fused with exit survey data of the Year 1 SmartGreen program.

Table 1 - Number of Employees

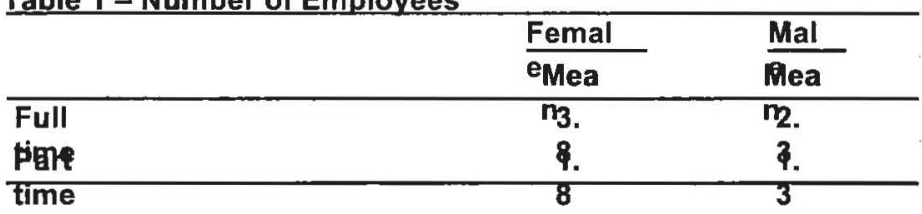

Table 2 - Turnover Last 12 months

\begin{tabular}{|c|c|c|}
\hline Month & $\frac{\text { Femal }}{\text { e}^{e_{\text {Coun }}}}$ & $\frac{\text { Mal }}{\text { Eoun }}$ \\
\hline fess than & 1 & 0 \\
\hline$\$ 59,880-$ & 2 & 2 \\
\hline$\$ 38 \theta ; 8$ 日日- & 0 & 0 \\
\hline$\$ 588$; 8 88 - & 1 & 0 \\
\hline \$1milliBh- & 1 & 1 \\
\hline
\end{tabular}


Table 3 - Information Sources about Environment \& Sustainability

\begin{tabular}{|c|c|c|}
\hline & Femal & Mal \\
\hline & $\mathrm{Ye}$ & eYe \\
\hline $\begin{array}{l}\text { Does your enterprise source information about } \\
\text { thefvironment and } \\
\text { sustainability? }\end{array}$ & $s_{4}$ & $\mathbf{s}_{3}$ \\
\hline Information of sustainability is & Coun & Coun \\
\hline Trom internet/the & 4 & 3 \\
\hline Werkshop & 3 & \\
\hline \$ & & 2 \\
\hline Word of mouth from friends & 3 & 0 \\
\hline $\begin{array}{l}\text { cegntacts } \\
\text { Televisio }\end{array}$ & 0 & 1 \\
\hline Radi & 1 & 0 \\
\hline
\end{tabular}

Table 4 - Frequency of Green Activities

\begin{tabular}{|c|c|c|c|c|c|c|}
\hline \multirow{2}{*}{$5=$ =always $1=$ never } & \multicolumn{2}{|c|}{ Femal } & \multicolumn{4}{|c|}{ Mal } \\
\hline & Mea e & Mod & Mea & e & Mor & \\
\hline Buv enerav efficient apoliances even if it costs & $n_{4}$ & e & $n$ & & e & 5 \\
\hline $\begin{array}{l}\text { Buy energy efficlent appliances even if it costs } \\
\text { more }\end{array}$ & $\begin{array}{l}4 . \\
0\end{array}$ & & $\begin{array}{l}4 . \\
0\end{array}$ & & & \\
\hline Buy from sustainably renewable sources even if it costs & 3 . & 4 & 4. & & & 3 \\
\hline more & 6 & & 0 & & & \\
\hline Recycle waste produced by your & 4. & 5 & 4. & & & 5 \\
\hline enterprise & 4 & & 7 & & & \\
\hline Use recycled & 3. & 4 & 4. & & & 3 \\
\hline products & 4 & & 0 & & & \\
\hline Conserve water in your & 4. & 4 & 3. & & & 2 \\
\hline $\begin{array}{l}\text { enterprise } \\
\text { Reduce appliance use in your enterprise to save }\end{array}$ & $\begin{array}{l}2 \\
4 .\end{array}$ & 4 & $\begin{array}{l}7 \\
3 .\end{array}$ & & & 2 \\
\hline energy & 0 & & 7 & & & \\
\hline Reduce energy use for heating and cooling in your & 3. & 4 & 4. & & & 5 \\
\hline
\end{tabular}

Table 5 - Behavioural Attitudes

\begin{tabular}{|c|c|c|c|c|c|}
\hline \multirow{2}{*}{$5=$ agree $1=$ disagree } & \multicolumn{2}{|c|}{ Femal } & \multicolumn{3}{|c|}{ Mal } \\
\hline & Mea $\bar{e}$ & Mod & Mea & $\overline{\mathrm{e}}$ & Mod \\
\hline Behaving in a sustainable way is important to my & $n_{5}$ & e & ${ }^{n} 5$. & & e \\
\hline enterprise & 0 & & 0 & & \\
\hline seaglde in a sustainable & 4. & 5 & 5. & & 5 \\
\hline $\begin{array}{l}\text { way } \\
\text { Joining others who are behaving in a sustainable way }\end{array}$ & 6 & & 0 & & \\
\hline ifnportant to & 5. & 5 & 5. & & 5 \\
\hline
\end{tabular}

Table 6 - Change in Operating more Sustainably

\begin{tabular}{|c|c|c|c|c|c|c|c|}
\hline \multirow{2}{*}{$5=$ uncertain } & \multirow{2}{*}{$4=$ major change } & \multicolumn{2}{|c|}{ Femal } & \multicolumn{4}{|c|}{ Mal } \\
\hline & & Mea e & Mod & Mea & e & Mod & \\
\hline In the past 2 & & $\begin{array}{ll}\mathbf{n} & 3 .\end{array}$ & e & $3 n$ & 3. & e & 3 \\
\hline vears next 2 & & 3. & & 3 & 3. & & 4 \\
\hline years & & 0 & & & 7 & & \\
\hline
\end{tabular}

Table 7 - Methods to make Green Changes 
Institute for Small Business \& Entrepreneurship isbe

3-6 November 2009 - Liverpool, UK

\begin{tabular}{|c|c|c|}
\hline $5=$ =always $1=$ never & $\frac{\text { Femal }}{\text { Eoun }}$ & $\begin{array}{l}\text { Mal } \\
\text { Eoun }\end{array}$ \\
\hline Discounts for & 3 & $\begin{array}{ll}\mathrm{t} & 3\end{array}$ \\
\hline products & 4 & 2 \\
\hline $\begin{array}{l}\text { Rractices } \\
\text { Advice and assistance from trades people on installing }\end{array}$ & 3 & 3 \\
\hline products & 4 & 3 \\
\hline Słstems business support & 2 & 2 \\
\hline Bựiness sustainability education and & 3 & 2 \\
\hline
\end{tabular}

training 
Table 8 - Knowledge of Environmental Issues

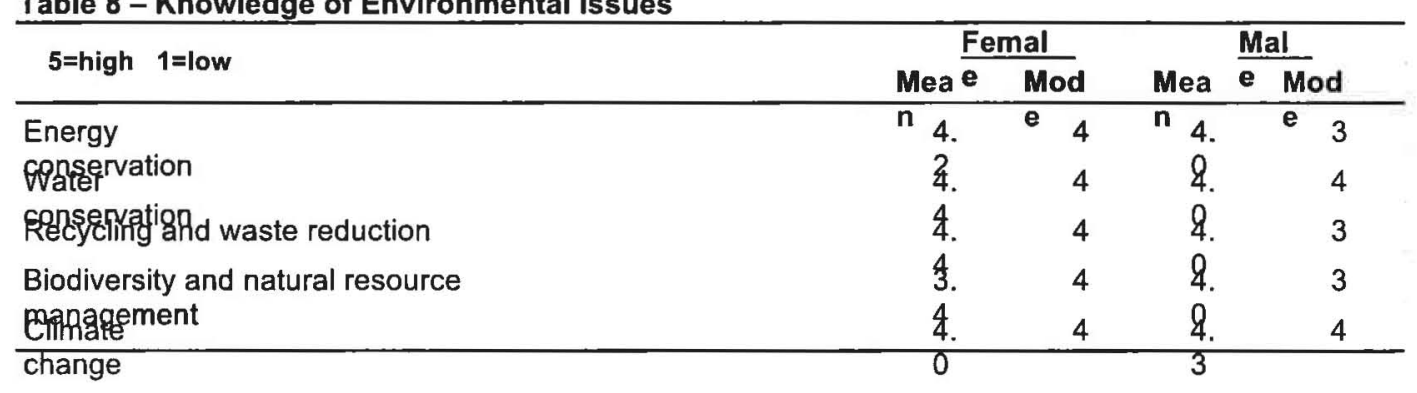

Table 9 - Common Beliefs

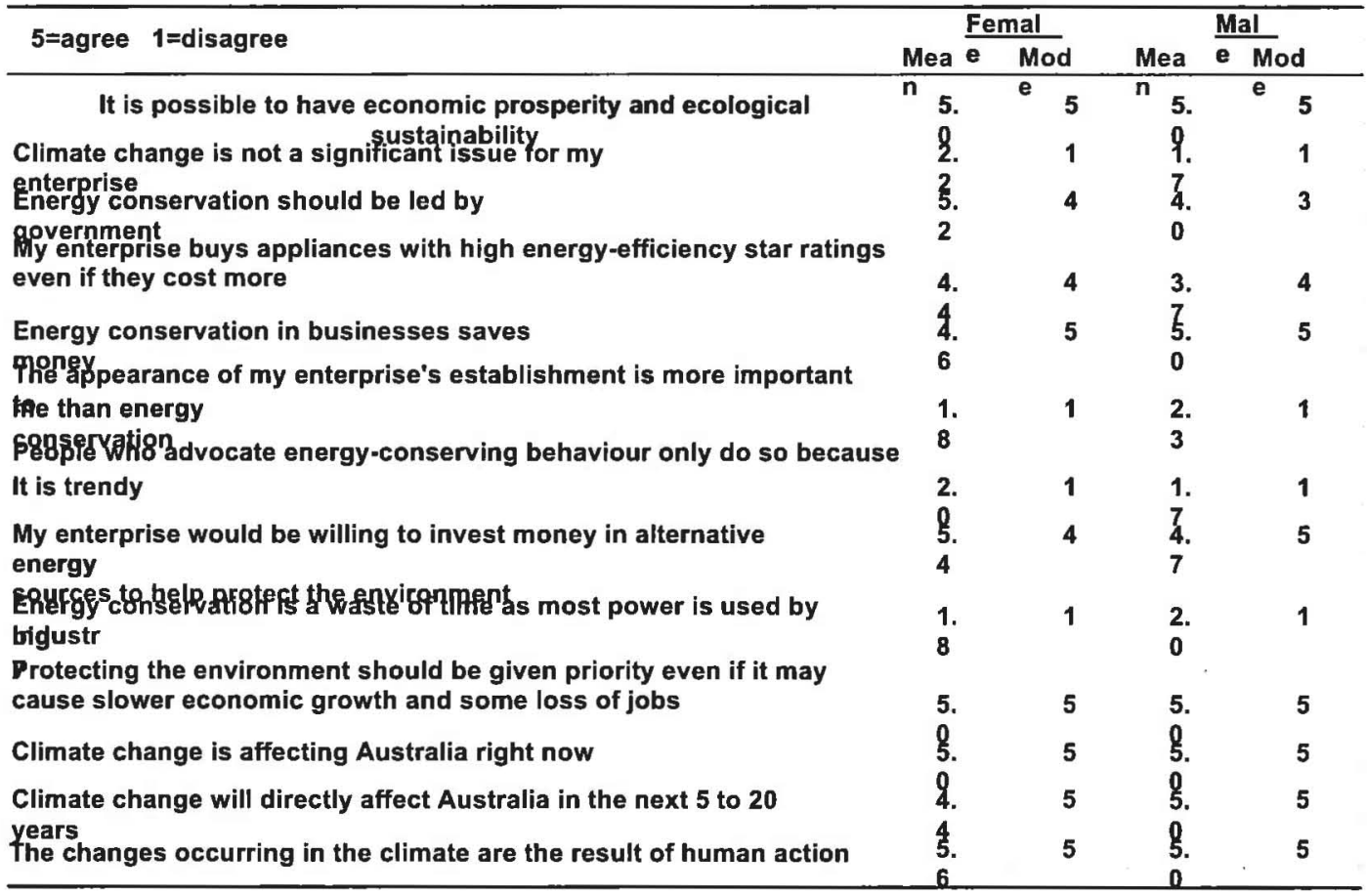


Table 10 - Cause of Climate Change

\begin{tabular}{|c|c|c|c|c|c|c|c|c|}
\hline \multirow{3}{*}{ 5=agree $1=$ disagree } & \multicolumn{4}{|c|}{ Femal } & \multicolumn{4}{|c|}{ Mal } \\
\hline & major & $\bar{e}$ & minor & & major & $\mathbf{e}$ & minor & \\
\hline & cauesun & & cauesun & & cauesun & & caue8un & \\
\hline Use of fuel for & $t$ & 5 & $t$ & 0 & $t$ & 2 & $t$ & 1 \\
\hline Eagapanty generation from & & 4 & & 1 & & 3 & & 0 \\
\hline EqRbr fossil fuel & & 5 & & 0 & & 3 & & 0 \\
\hline Aşficulture and & & 2 & & 2 & & 2 & & 1 \\
\hline 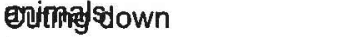 & & 5 & & 0 & & 2 & & 1 \\
\hline tfens we & & 4 & & 1 & & 1 & & 2 \\
\hline
\end{tabular}

Table 11 - Entrepreneurial Attitudes

\begin{tabular}{|c|c|c|c|c|}
\hline $5=$ agree $1=$ disagree & $\begin{array}{l}\text { Femal } \\
\text { Fea }\end{array}$ & Mod & $\begin{array}{l}\text { Mal } \\
\text { Mea }\end{array}$ & Mod \\
\hline $\begin{array}{l}\text { In general, my enterprise favours a strong emphasis on providing } \\
\text { tiriadtrue products and } \\
\text { services }\end{array}$ & $\begin{array}{l}3 . \\
6\end{array}$ & $\mathbf{e}$ & $\begin{array}{l}\mathbf{n} \\
\mathbf{5}\end{array}$ & e \\
\hline $\begin{array}{l}\text { The number of new lines of products or services during the past } 3 \\
\text { years }\end{array}$ & $\begin{array}{l}3 . \\
8\end{array}$ & 4 & $\begin{array}{l}4 . \\
0\end{array}$ & 4 \\
\hline $\begin{array}{l}\text { The degree of changes in product or services line during last } 3 \\
\text { years }\end{array}$ & 4. & 4 & 3. & 4 \\
\hline $\begin{array}{l}\text { In dealing with its competitors, my enterprise typically initiates } \\
\text { ectionsh competitors then } \\
\text { respond }\end{array}$ & $\begin{array}{l}4 . \\
0\end{array}$ & 3 & $\begin{array}{l}3 . \\
3\end{array}$ & 3 \\
\hline $\begin{array}{l}\text { In dealing with its competitors, my enterprise is very often the } \\
\text { Eraterprise to introduce new products or services, } \\
\text { etc. }\end{array}$ & $\begin{array}{l}4 . \\
0\end{array}$ & 4 & $\begin{array}{l}3 . \\
7\end{array}$ & 4 \\
\hline $\begin{array}{l}\text { In dealing with its competitors, my enterprise typically adopts a } \\
\text { corwpetitive, "undo-the-competitors" } \\
\text { posture }\end{array}$ & $\begin{array}{l}3 . \\
4\end{array}$ & 3 & $\begin{array}{l}4 . \\
0\end{array}$ & 3 \\
\hline $\begin{array}{l}\text { In general, my enterprise has a strong preference for high risk } \\
\text { briftectsances of very high } \\
\text { returns) }\end{array}$ & $\begin{array}{l}3 . \\
6\end{array}$ & 4 & $\begin{array}{l}4 . \\
3\end{array}$ & 4 \\
\hline $\begin{array}{l}\text { In general, I believe that owing to the nature of the } \\
\text { bavinament, bold, wide-ranging acts are necessary to } \\
\text { achieve }\end{array}$ & $\begin{array}{l}3 . \\
6\end{array}$ & 3 & $\begin{array}{l}3 . \\
3\end{array}$ & 4 \\
\hline
\end{tabular}

enterprise's objectives

\section{Discussion}

As observed above, the numbers in the entry survey did not allow for in-depth analysis and the following discussion is based on indicative results.

Overall, respondents indicate that green practices are important to their enterprise. Negligible differences could be detected between genders in terms of attitudes towards the environment and related business practices. Being seen to behave in a sustainable manner was important to both men and women. There was some gender difference in entrepreneurial orientation and level of risk taking vis-à-vis new business practices, with women generally inclined to take less risk than male entrepreneurs favouring a strong emphasis on tried and true products and services, which corresponds with findings on the propensity of risk taking in the literature (Meier \& Masters, 1988). Neither gender were looking at major changes in their business over the next two years.

Both men and women indicated that they sourced their environmental information from the Internet, followed by workshops and printed literature. Recycling and water conservation were the most common green activities undertaken by participating entrepreneurs. Similarly, both genders rated their knowledge of environmental issues, including climate change, energy and water use as relatively high, although females' ratings of environmental causes such as fossil fuels, energy use and purchases were higher than males. Women were more willing to invest in alternative energy to help the environment, while men were more inclined to buy products or services from sustainably renewable sources even if it costs more. 
These results indicate that at the outset of the 2009 program there were no significant differences where men and women entrepreneurs are concerned, so gender comparisons based on essentialist characteristics pertaining to environmental attitudes and behaviour, could not be made.

Reflecting on the outcomes of the 2009 entry survey, it is important to consider potentially mitigating factors pertaining to these results. Year 2 participation SMEs are yet to complete the SmartGreen program and many have not have started environmental action plans for their enterprise. As such, we can only consider survey responses as self-reported intentions that may have a stronger link to attitudes than reality (Stern, 1992). Moreover, people often overestimate the benefits of their behavioural choices and methods of self-monitoring can be ineffective with social desirability influencing reporting. Similarly, environmental awareness does not equate to actual impact on behaviour, which in turn can result in misdirected action (Gaterseleben et al, 2002). Thus, professed pro-environmental values, attitudes and knowledge will not necessarily translate into behavioural change by either women-led or male-led enterprises.

The study then went on to compare Year 2 outcomes to the Year 1 results, which were a combination of the responses of the Year 1 exit survey, program participation records and in-class observations of participants during the SmartGreen 2008 program. Year 1 businesses attended nine (monthly) workshops, designed and completed individual environmental action plans for their business. Quantative data collected during the Year 1 program predominantly focused on the optimisation of program content and delivery, which fall outside of the scope of this paper. Salient attendance observations and qualitative responses captured in the exit survey are highlighted below.

Of the initial number of participants (30), most of which were in micro or SME enterprises, a number of men (6) either dropped out of the program citing issues such as 'too busy' and 'am already doing most of this stuff' or replacing themselves with a woman colleague citing her to be 'better placed to undertake and implement the SmartGreen program'. All women participants (15) who signed up for the program finished the program with women entrepreneurs generally eager to gather and contribute information to the classroom; share information on course content in their workplace and network with other participants. Thus, participatory differences were observed between the male and female entrepreneurs that took part in the program.

Whereas participating women saw themselves as agents of change in leading the greening of their own business into profound social change, men saw it as an opportunity for leaner business practices and operational savings, providing comments such as: "The owners and management are committed to a process that will minimise the impact of these activities on the environment"; Not sure where this is all headed.." Female responses included [referring to some of the male participants]: "Are the participants all committed to being 'green entrepreneurs' or is it mainly for business building of conventional businesses who wish to tap into the green market, but may not be committed to 'green' direction in their product/manufacturing?"

Interestingly, both genders looked to government to lead climate change actions, although a female participant commented that "business can and need to lead the way to solve our environmental issues towards a more sustainable society". Comments on whether the SmartGreen program changed their business practices by men included "I feel we didn't get down to the real reason most people are attending - how they can make $\$ \$$ out of sustainability". Female participants: "SmartGreen was a catalyst for us to implement our waste management system. The program encouraged us to make more environmentally friendly decisions in relation all aspects of our business".

Comments by men participants on the value of the course included "the program made me think, but it would have been useful if we had more in the same industry." Female participants' comments included: "What I learnt is that it doesn't cost a lot"; "being informed is being armed"; "knowing what questions to ask is half the battle"; "a standard to work towards makes life easier"; and "I feel good about where my business is headed".

Exit survey comments by male participants on the value of networking during the course included: "The group was too small for useful networking", whereas female participants expressed the opposite view: "Meeting other business people was great, learning what is available in our area is always useful" and "SmartGreen has provided an opportunity to discuss environmental issues affecting organisations and to network with like-minded folks in the local area". 
While exit survey numbers were again relatively small, findings from Year 1 do suggest that womenled SMEs have different motivations than male entrepreneurs in pursuing green business practices. Male entrepreneurs tended to look for bottom line outcomes and competitive advantage, whereas women tended to lean towards broader ethical concerns (Paulray, 2008) in terms of benefitting the greater good. Women were also more proactive in participating in green networking opportunities, where they can interact with like-minded businesses, access more clients, source alternative resources and expand their business networks.

\section{Conclusion}

This paper has discussed the role of women entrepreneurs' in proactively greening their small business. The paper presented the combined outcomes of the exit survey of a greening small business 2008 pilot program and the entry survey for the 2009 online version of the training and networking program, which fuses environmental, business and ICT-enabled skilling to enhance both SME entrepreneurship and innovation.

The study suggests that while reported attitudes between male and female entrepreneurs do not differ significantly, women's motivations differ from male entrepreneurs in pursuing green business practices and participating in green networking opportunities. While this may translate into exciting new opportunities for women entrepreneurs in terms of green business practices, new business opportunities, innovation, the generation of green jobs and the laying of sustainable foundations for the post-industrial economy, many questions remain and new questions have been raised. Were women more proactive because of their interest in wider social outcomes? Were they more proactive because they generally have less opportunity to network? Are female approaches to business and entrepreneurship more suited to green enterprise? Are manufacturing businesses in a better position than service sector businesses to pursue green practices?

In reviewing above outcomes in light of the Theory of Planned Behaviour (Azjen, 1992), which focuses on innovation attributes for attitude formation and communication, it appears that individual knowledge, awareness, intention and behaviour are closely related and that different information and communication channels/networks do influence decision making processes. Thus, observed gender differences in awareness, knowledge gathering and social orientation may prove to be important determinants for the uptake of green entrepreneurship in small business environments.

This is a relatively new and timely area of research, so many questions remain and many new questions have arisen. There is much scope for further research in the gender and green entrepreneurship arena, and in particular what motivates women entrepreneur to take up green practices and a need to expand our understanding of why and how women-led firms embrace environmentally friendly practices and networks. There are questions around whether gender differences impacts this trajectory; what impacts the rate of adoption of green practices and whether this is industry-specific; how we can utilise Web 2.0 technologies and social networking to influence green supply chain formulation and green purchasing, to name but a few. This study will be ongoing and once the dataset is expanded, it is anticipated that a more in-depth analysis will be provided to help address some of these questions.

\section{References:}

Abrahamse, W., Steg, L., Vlek, C. \& Rottengather, T. (2005). A review of intervention studies aimed at household energy conservation. Journal of Environmental Psychology, 25, pp. 273-291

Ajzen, I. (1992). The Theory of Planned Behavior, Organizational Behavior and Human Decision Processes, 50(2), pp. 179-211

Bansal, P. \& Roth, K. 2000. Why companies go green: a model of ecological responsiveness, Academy of Management Journal, 43(4), 717.

Dixon, S. \& Clifford, A. 2007. Ecopreneurship - a new approach to managing the triple bottom line, Journal of Organizational Change Management, 20(3), 326-345.

Dunlap, R. and Van Liere, K. (1978). The New Environmental Paradigm: A proposed measuring instrument and preliminary results. Journal of Environmental Education, 9, pp. 10-19

Dunlap, R., Van Liere, K., Mertig, A. \& Emmet J., R. (2000). Measuring Endorsement of the New Ecological Paradigm: A Revised NEP Scale. Journal of Social Issues, 56(3), pp. 425-442 
Environment Victoria. 2009. Victoria - the Green Jobs State: Seizing the Opportunities, Melbourne: Environment Victoria.

Fishbein, M., \& Ajzen, I. (1975). Belief, attitude, intention, and behavior: An introduction to theory and research. Reading, MA: Addison-Wesley.

Gatersleben, B., Steg, L., \& Vlek, C. (2002). Measurement and determinants of environmentally significant consumer behavior. Environment and Behavior, 34(3), pp. 335-362.

Guagnano, G., Stern, P. \& Dietz. T. (1995). Influences On Attitude-Behavior Relationships: A Natural Experiment With Curbside Recycling, Environment and Behavior, 27, pp.699-718

Isaak, R. (1999): Green Logic: Ecopreneurship, Theory and Ethics. West Hartford: Kumarian Press.

Lepoutre, J. 2008. Proactive Environmental Strategies in Small Business: Resources, Institutions and Dynamic Capabilities. Unpublished Thesis, Gent University.

Lepoutre, J. and Valente, M. 2007. A resource-based perspective on small business proactive social and environmental strategies. Paper presented at Ivey School of Business, London, Ontario, Canada.

Lutzenheiser, L. (1993). Social and behavioural aspects of energy use. Annual Review of Energy and Environment, 18, pp. 247-289

Meier, R. \& Masters, R. (1988). Sex Differences and Risk-Taking Propensity of Entrepreneurs. Journal of Small Business Management, Vol. 26, 1988

Paulray, A. (2008). Environmental Motivations: a Classification Scheme and its Impact on Environmental Strategies and Practices, Business Strategy and the Environment, accessed online 18/08/09 from http://www.mysmartgreen.com.au/members/resources/ EnvironmentalMotivations a classificationscheme.pdf

Stern, P. (1992). Psychological dimensions of global environmental change, Annual Review of Psychology, 43, pp. 269-302.

Stern, P. (2000). Toward a Coherent Theory of Environmentally Significant Behavior, Journal of Social Issues 56(3), pp. 407-424.

Stern, P., Dietz, T., Abel, G., Guagnano, A. \& Kalof, L. (1999) A Value-Belief-Norm Theory of Support for Social Movements: The Case of Environmentalism, Human Ecology Review, 6(2), pp. 81-97.

Werbach, A. 2009. Strategies for Sustainability. New York: Perseus.

Wilson, C. and Dowlatabadi, H. (2007) Models of decision making and residential energy use. Annual Review of Environment and Resources, 32, pp. 169-203. 